\title{
The Heat Treatment of Aluminium Bronzes
}

Jiří Hájek, Antonín Kříž, Václav Hrdlička

Západočeská Univerzita v Plzni, Univerzitní 22, 30614 Plzeň, Czech Republic. E-mail: hajek@kmm.zcu.cz, kriz@kmm.zcu.cz, hrdlicka@kmm.zcu.cz.

\begin{abstract}
Aluminium bronzes can find use in many engineering applications thanks to their excellent properties, predominantly high corrosion resistance, good ultimate tensile strength, fatigue strength and creep strength. Yet, their mechanical properties can still be improved, most importantly by appropriate heat treatment. The type of heat treatment is typically chosen with regard to the desired properties of the product and its service conditions.

This paper attempts to summarise the microstructural changes which take place in aluminium bronzes during heat treatment. Another objective of this study was to map the potential of a certain type of aluminium bronzes for undergoing martensitic transformation. The methods, which were chosen for assessing the results of heat treatment with regard to their availability, included measurement of hardness and observation of microstructure using light and scanning electron microscopy, Additional tools for evaluation of microstructure comprised measurement of microhardness and chemical analysis by EDS.
\end{abstract}

Keywords: Aluminium bronzes, Heat treatment, microstructure, EDS

\section{Acknowledgement}

The present paper is based on activities carried out in the project SGS - 2012-044.

\section{References}

[1] KRAUS, V. (2000). Lecture notes of the Západočeská Univerzita v Plzni, Tepelné zpracování a slinování, Plzeň.

[2] FRANC, A. (2005). Diploma thesis, Problematika navařováni hlinikových bronzů na ocel 15241, Západočeská Univerzita v Plzni.

[3] CULPAN, E. A. ROSE, G. (1978). Microstructural characterization of nickel aluminium bronze, Journal of Materials Science 13,

[4] SABOKTAKIN, M. R., HOSSEIN, K. (2014). Microstructure evolution and microhardness of friction stir welded cast aluminum bronze, Journal of Materials Processing Technology Volume 214, Issue 8, August, Pages 15241529

[5] ANANTAPONG, V. UTHAISANGSUK, S. SURANUNTCHAI, MANONUKUL, A. (2014). Effect of hot working on microstructure evolution of as-cast Nickel Aluminum Bronze alloy, Materials \& Design, Volume 60, August, Pages 233-243

[6] HURTALOVÁ, L. TILLOVÁ, E. Elimination of the negative effect of Fe-rich intermetallic phases in secondary (recycled) aluminium cast, In: Manufacturing Technology, Volume 13, pages 44-50

[7] GREGER, M. WIDOMSKÁ, M. Analysis of influence of structure on mechanical properties of AlSiMg aluminium alloy processed by ECAP, In: Manufacturing Technology, Volume 11, pages 17-22

[8] GÓRECKI, T., KRÓL, S., TOKARSKI, M. Effect of the Rate of Continuous Cooling from the $\beta$ Phase Region on the Phase Composition Structure and Properties of Cu-10Al-3Fe-2Mn Aluminium Bronze: Journal Institute of Metals, 1978.

[9] http://www.leco.com/resources/application_note_subs/pdf/metallography/Met\%20Principles\%20and\%20Procedures\%20Catalog\%20200-860.pdf

[10] http://www.cda.org.uk/megab2/corr_rs/pub83-al-bronze-alloys-for-industry.pdf 